\title{
Development of uniaxially driven biaxial tensile testing method using microminiature specimen of thin thickness
}

\author{
Yasuhiro HANABUSA* ${ }^{*}$, Hideo TAKIZAWA** and Toshihiko KUWABARA***
}

We have established a biaxial tensile test method suitable for the measurement of the local plastic deformation characteristics of a hard aluminum alloy sheet 3104-H, which is a typical material for aluminum can bodies, as a representative of the low work hardening materials. The present method consists of the following: (1) a microminiature cruciform specimen, (2) a newly designed linkage mechanism mounted on a uniaxial tensile testing machine, and (3) the loading path diagram as an experimental method to measure the biaxial stress-strain curves accurately from the biaxial tensile tests with linear displacement paths of the chucking jigs. The following are drawn from the biaxial tensile tests for the thin test material: (i) using the proposed biaxial tensile testing apparatus, we measured a contours of plastic work, and it was in good agreement with that measured using the conventional linear stress path tests, (ii) we were successful to determine the real yield points for various biaxial tensile states using the loading path diagrams and to measure the contour of plastic work corresponding to the maximum equivalent plastic strain of 0.0012 , and (iii) the contour of plastic work is well approximated using the Yld2000-2d yield function with an exponent of 7.78 .

(Received September 26, 2013 Accepted December 18, 2013)

Keywords: biaxial tensile test, cruciform specimen, contours of plastic work, hard aluminum alloy sheet, yield criterion

\section{1. 緒言}

飲料用アルミニウム DI 缶（以下アルミ缶）は，省資源· 省エネルギーの観点から高強度化による軽量化が進められて いる ${ }^{1)}$ 。一方で，製品差別化のための意匠としてアルミ缶側 壁部に凹凸形状を加工する場合がある。このような薄肉化, 形状の複雑化に対応する強度設計および加工条件の適正化の ためには,アルミ缶側壁部の塑性変形特性の正確な把握が求 められる。

著者らは既報において，任意の応力・ひずみ経路を円管材 に負荷することができる軸力ー内圧型二軸応力試験機を用い て, アルミ缶側壁部の変形特性や破断挙動の異方性を明らか

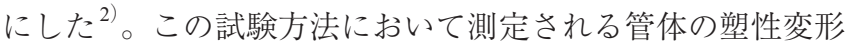
特性は，缶側壁部中央部のそれであり，かつ円周方向に平均 化された測定值である。しかし，塑性異方性を持つ圧延板か ら DI加工によって成形されるアルミ缶の場合, 側壁の機械 的特性は, 円周方向および午軸方向のいずれの位置において も異なる塑性変形特性を持つ。よって上記の試験方法は, 缶 体の塑性変形特性の異方性評価方法としては完全ではない。
二軸応力場における板材の塑性変形特性を測定する試験法

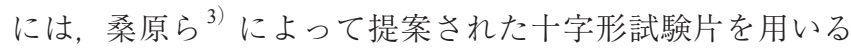
方法がある。この方法を用いれば，試験片を小型化すること で二軸応力下での局所的な塑性変形特性を測定することがで きる。しかしながら, アルミ午側壁部から切出す試験片は, 小型・薄肉であることに加え, 加工硬化が小さいことから, 試験片形状の追加検討およびひずみゲージによらないひずみ 測定が必要不可欠である。

また, 一般に十字形試験片を用いる二軸応力試験には直交 する二軸負荷を制御する特殊な専用試験機が必要となる。こ れに対して永安ら ${ }^{4)}$ は圧縮試験機を用いた二軸試験装置を 開発しており, 一般的な単軸試験機による二軸試験を可能に した。しかし，この装置は高張力鋼板などを対象とした大き な荷重容量の試験装置であり, 薄肉材の小型試験片は対象と していない。

本研究では, 負荷荷重が小さいことを考慮し，汎用の単軸 引張試験機を駆動源とする簡便さはそのままに，新たな等変 位機構を実現するリンク機構を用いた二軸引張試験方法を提 案する。そしてこの試験装置を用いて, 加工硬化の小さい

*ユニバーサル製缶(侏) 開発部（广410-1392 静岡県駿東郡小山町菅沼 1500）。Development Department, Universal Can Corporation (1500 Suganuma, Oyama-cho, Sunto-gun, Shizuoka 410-1392).E-mail: hanabusa@unican.co.jp

** 日本工業大学機械工学科 (埼玉県南埼玉郡)。Mechanical Engineering Deptartment, Nippon Institute of Technology (Minami-Saitama-gun, Saitama).

***東京農工大学大学院工学研究院先端機械システム部門 (小金井市)。Division of Advanced Mechanical Systems Engineering, Institute of Engineering, Tokyo University of Agriculture and Technology (Koganei-shi, Tokyo). 
A3104-H板材から切出した薄肉・超小型の十字形試験片を用 いて，二軸応力下での塑性変形特性を測定することに成功し たので報告する。

\section{2. 二軸引張試験方法の開発}

\section{1 単軸引張試験機を用いた二軸引張試験装置の開発}

本節では，負荷荷重が小さい二軸引張試験に適するよう開 発したリンク装置を説明する。水平方向 $(x$ 方向）と鉛直方 向 $\left(y\right.$ 方向) に等二軸変位（変位比 $U_{x}: U_{y}=1: 1$ ) を付与する リンク機構を Fig. 1(a)に示す。この機構では, 最上部にある 継手部を単軸引張試験機のクロスヘッドに取付け，これを上 昇させることにより，駆動リンクを介して回転板を時計回 りに回転させる。この回転により，90度間隔で等分に配置 された4つの従動リンクが，直交する二軸上でスライダを四 方に広がるように水平・鉛直方向へ移動させる。このスラ イダに取付けたチャックが十字形試験片の4つの腕部を引張 り，等二軸変位を付与することができる。また，Fig. 1(b)に 示すように水平方向変位 $U_{x}$ を生じさせる従動リンクの長さ と回転板上での接続位置を変更することによって，変位比を $U_{x}: U_{y}=2: 1$ へ容易に変更することができる。なお，水平方向 変位 $U_{x}$ を生じさせる従動リンクを回転板から外し，チャッ クをスライダ上で固定すれば, 変位比 $U_{x}: U_{y}=0: 1$ の試験も可 能である。

さらに本試験機の特長は, 試験開始から終了まで変位比 $U_{x}: U_{y}=n: 1$ を一定に保つことができる点である。この原理を Fig. 2 に示す変位比 $U_{x}: U_{y}=2: 1$ のリンク機構模式図を用いて 説明する。図中の添字 0 は初期配置を，添字 1 は変位後の状 態を示し，リンク機構の各諸元を次のように定める。

$L_{c}:$ 駆動リンクの長さ。

$L_{s}:$ 鉛直方向変位を生じさせる従動リンクの長さ。

$L_{d}$ : 水平方向変位を生じさせる従動リンクの長さ。 $L_{d}=n L_{s}$ 。

$r$ : 鉛直方向に変位する従動リンクの回転板取付け点と中 心Oを結ぶ長さ。

$R$ : 水平方向に変位する従動リンクの回転板取付け点と中 心 $\mathrm{O}$ を結ぶ長さ。また, $R$ を示す直線と $r$ を示す直線 は直交し， $R=n r$ という関係がある。

$\alpha$ : 駆動リンクの回転板取付け点と中心 $\mathrm{O}$ を結ぶ直線が鉛 直方向となす角度。

$\varphi$ ：鉛直方向に変位する従動リンクが鉛直方向となす小さ い方の角度。

試験開始前における，回転板中心 $\mathrm{O}$ から各従動リンク端点

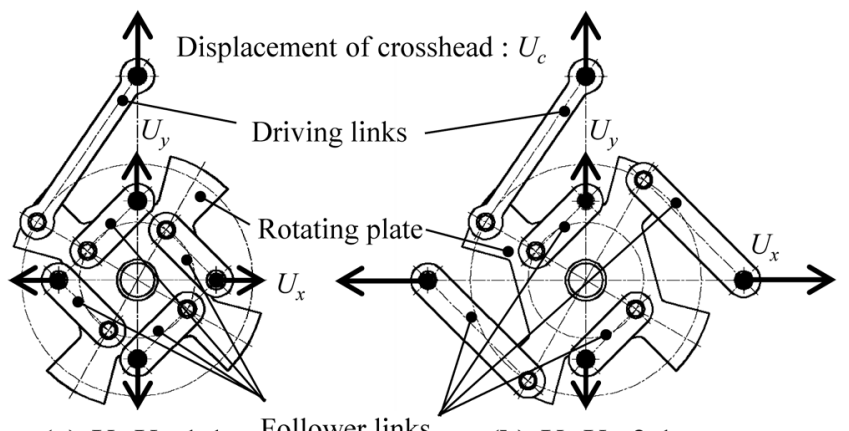

$\begin{array}{lll}\text { (a) } U_{x}: U_{y}=1: 1 \quad \text { Follower links } & \text { (b) } U_{x}: U_{y}=2: 1\end{array}$

Fig. 1 Linkage mechanism.

$B_{0}, C_{0}$ までの長さは以下のように表される。

$$
\begin{aligned}
& \overline{O B_{0}}=L_{s} \cos \varphi_{0}+r \cos \alpha_{0} \\
& \overline{O C_{0}}=L_{d} \cos \varphi_{0}+R \cos \alpha_{0}
\end{aligned}
$$

変位後の回転板中心 $\mathrm{O}$ から各従動リンク端点 $B_{1}, C_{1}$ までの 長さは同様にして次式によって求めることができる。

$$
\begin{aligned}
& \overline{O B_{1}}=L_{s} \cos \varphi_{1}+r \cos \alpha_{1} \\
& \overline{O C_{1}}=L_{d} \cos \varphi_{1}+R \cos \alpha_{1}
\end{aligned}
$$

水平方向变位 $U_{x}$, 鉛直方向変位 $U_{y}$ は次式より求める。

$$
\begin{aligned}
U_{y} & =\overline{O B_{1}}-\overline{O B_{0}} \\
& =\left(L_{s} \cos \varphi_{1}+r \cos \alpha_{1}\right)-\left(L_{s} \cos \varphi_{0}+r \cos \alpha_{0}\right) \\
& =L_{s}\left(\cos \varphi_{1}-\cos \varphi_{0}\right)+r\left(\cos \alpha_{1}-\cos \alpha_{0}\right) \\
U_{x} & =\overline{O C_{1}}-\overline{O C_{0}} \\
& =\left(L_{d} \cos \varphi_{1}+R \cos \alpha_{1}\right)-\left(L_{d} \cos \varphi_{0}+R \cos \alpha_{0}\right) \\
& =L_{d}\left(\cos \varphi_{1}-\cos \varphi_{0}\right)+R\left(\cos \alpha_{1}-\cos \alpha_{0}\right)
\end{aligned}
$$

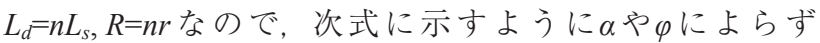
チャックの変位比は常に保たれる。

$$
\begin{aligned}
U_{x} & =n\left\{L_{s}\left(\cos \varphi_{1}-\cos \varphi_{0}\right)+r\left(\cos \alpha_{1}-\cos \alpha_{0}\right)\right\} \\
& =n U_{y}
\end{aligned}
$$

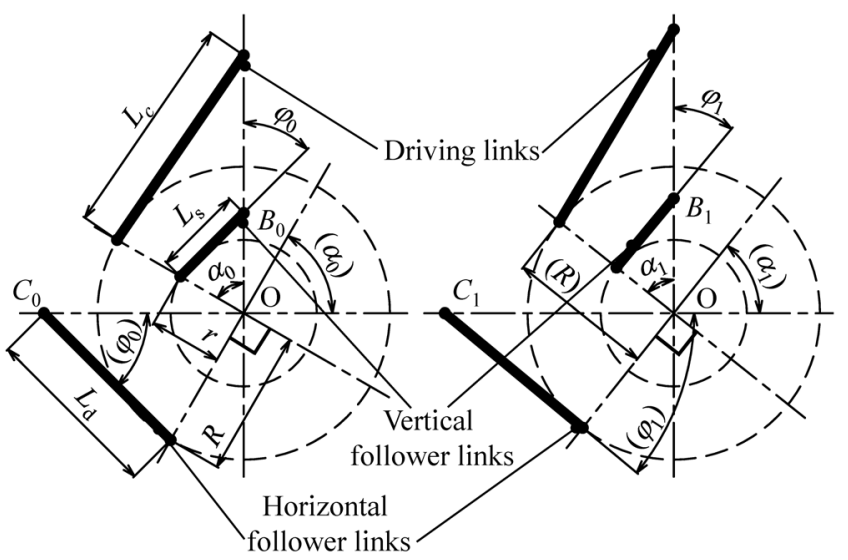

(a) Initial configuration

(b) Current configuration

Fig. 2 Schematic diagram of linkage mechanism on $U_{x}: U_{y}=2: 1$. The index 0 means initial configuration (a), and the index 1 means current configuration (b).

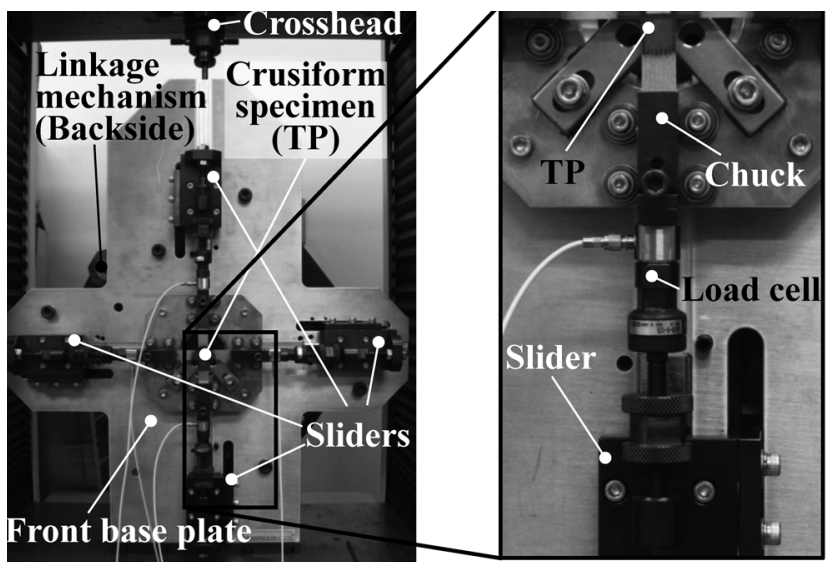

(a) Front appearance

(b) Chuck and slider

Fig. 3 Biaxial tensile apparatus in tensile testing machine. 
ただし, 変位比 $U_{x}: U_{y}=0: 1$ の試験では $\overline{O C_{0}}=\overline{O C_{1}}=$ const. と なるため $U_{x}=0$ となる。

開発した試験装置は，Fig. 3 に示すように汎用の引張試験 機へ直立型で設置する。本試験機では荷重の対称性を確認す

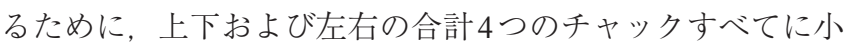
型のロードセル（最大荷重 $20 \mathrm{kN}$ ）を設置している。単軸変 位を二軸変位に変換する機能は，すでに提案されている簡易 型二軸引張試験装置 ${ }^{4), 5)}$ と同様だが, 本試験機は, 直立型 にすることで試験片正面を開放しているため, CCDカメラ を用いた非接触ひずみ測定が可能である。また，正面を開放 することで試験片設置の作業性も大幅に改善できる。

\section{2 超小型薄肉試験片の形状}

Fig. 4(a)に十字形試験片の諸寸法を示す。これらは応力測 定誤差を最小化するための形状として著者らが検討した結 果 ${ }^{6)}$ にもとついて定めた。

一般に十字形試験片では，二軸応力場となる応力測定 部（中心の正方形領域）よりも単軸応力場となる腕部が先に 降伏する。加工硬化が大きい材料では，腕部が加工硬化する ことで応力測定部を塑性変形させることができる。しかし, $\mathrm{H}$ 材は加工硬化が小さいため, 腕部での十分な強度増加を 望めない ${ }^{6)}$ 。そ己で本試験片では，スリットをファイバレー ザ7）で加工することで，スリット幅 $w_{s} を 50 \mu \mathrm{m}$ として，荷重 を負担する腕部の断面積の減少を必要最小限に抑制した。ま た，スリット長さ $L$ を応力測定部の幅 $B$ の 2 倍として，腕部 の曲げ変形抵抗を抑制することで，腕部に発生する付加的な 応力が小さくなるよう工夫した。

\subsection{CCD カメラによる非接触ひずみ測定方法}

超小型薄肉試験片では, 試験荷重が小さいため, ひずみ

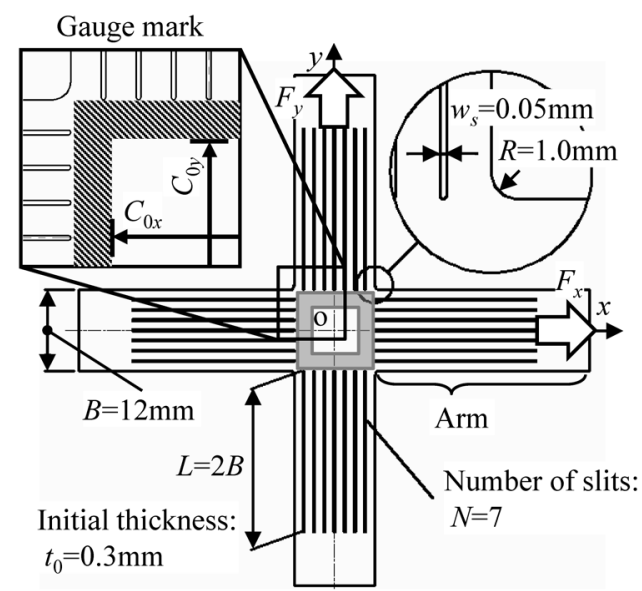

(a) Geometry of cruciform specimen

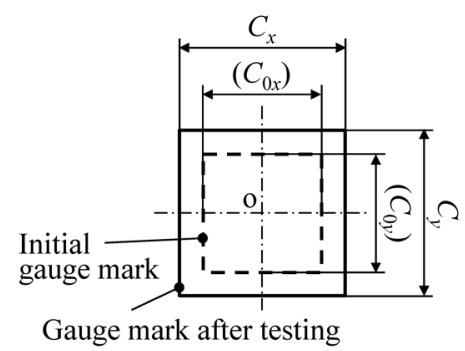

(b) Dimensions of the gauge mark after testing

Fig. 4 Geometry of the cruciform specimen for the biaxial tensile tests.
ゲージ自体の剛性および強度が試験片の応力測定部の変形に 及ぼす影響を無視できない。このため, 本試験ではCCDカ メラを用いた非接触ひずみ測定を行う。

著者らは応力測定誤差が最小となるひずみ測定位置を提案 しているが6),8), 超小型試験片においては，局所的なひずみ を測定することは困難である。そこで，Fig. 4 に示すように 応力測定部の直交する負荷軸上に適切な標点距離を考え, こ の標点距離の変化（標点の変位）により，ひずみを算出する。 水平方向および垂直方向の標点距離をそれぞれ $C_{0 x}$ および $C_{0 y}$ とする。また, 試験後の水平方向および垂直方向の標点距離 をそれぞれ $C_{x}, C_{y}$ とする。これらの標点距離から対数ひずみ $\varepsilon_{x}, \varepsilon_{y}$ および真応力 $\sigma_{x}, \sigma_{y}$ は以下の式で表される。ここで $F_{x} お$ よび $F_{y}$ は試験荷重, $t_{0}$ は初期肉厚, $B$ は応力測定部の幅を示 す。

$$
\begin{aligned}
& \varepsilon_{x}=\ln \left(C_{x} / C_{0 x}\right), \quad \varepsilon_{y}=\ln \left(C_{y} / C_{0 y}\right) \\
& \sigma_{x}=F_{x} \exp \left(\varepsilon_{x}\right) / B t_{0}, \quad \sigma_{y}=F_{y} \exp \left(\varepsilon_{y}\right) / B t_{0}
\end{aligned}
$$

応力測定部の幅 $B$ に対する標点距離の比 $C_{0 x} / B, C_{0 y} / B$ は 0.3 0.8の範囲では各軸方向の応力 -ひずみ関係へほとんど 影響しないことを有限要素解析によって確認している ${ }^{9)}$ 。そ こで本研究では，標点マーキング（標点距離を辺とする矩形 領域をマスキングして外側に黒色塗料をスプレーで塗布）の 作業性から標点距離を $C_{0 x}=C_{0 y}=0.7 B$ とした。

\section{4 実験例と弾性域の取扱い}

本節では，ここまで述べた試験方法によって得られた実験 結果の例を示す。

変位比 $U_{x}: U_{y}=2: 1$ の二軸引張試験において, 各チャックに 取付けたロードセルによって測定された荷重の関係を Fig. 5 に示す。上下および左右の荷重はほぼ同じ測定值を示してお り, 十字形試験片は装置中心で均等にそれぞれの方向へ引張 られていることが確認できた。

変位 $U_{x}=4.3 \mathrm{~mm}\left(U_{y}=2.15 \mathrm{~mm}\right)$ を与えたときの応力測定部 の標点マークの変形の様子を Fig. 6 に示す。マーキングされ た領域はほぼ矩形を維持して拡大している。

変位比 $U_{x}: U_{y}=2: 1$ の二軸引張試験で得た応力 -ひずみ曲線 をFig. 7 に示す。水平方向の応力-ひずみ曲線の拡大図では, 弾性域におけるひずみ測定值が大きく変動する。これは, 本 試験装置で用いるCCDカメラ像の分解能が低いことに起因 する。また, 別の問題として, 応力ーひずみ曲線は原点を通 らない。これは, 試験片取付け時に生じる面外方向のたわみ を除去するために，予荷重を負荷しているためである。

これらの問題に対し，降伏点を基準とし，既定のヤング率 $E$, ポアソン比 $v$ 用いて, ひずみ測定值を以下の手順によ

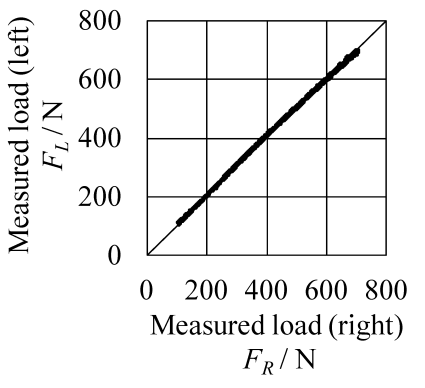

(a) Horizontal direction

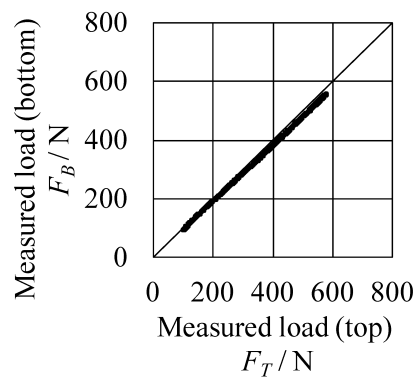

(b) Vertical direction
Fig. 5 Loading paths measured for $U_{x}: U_{y}=2: 1$. 


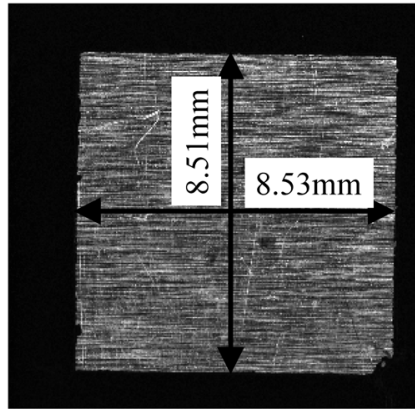

(a) Initial gauge mark

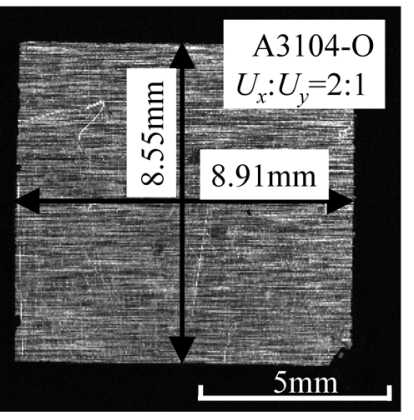

(b) After testing

Fig. 6 Gauge mark on the cruciform specimen (CCD image).

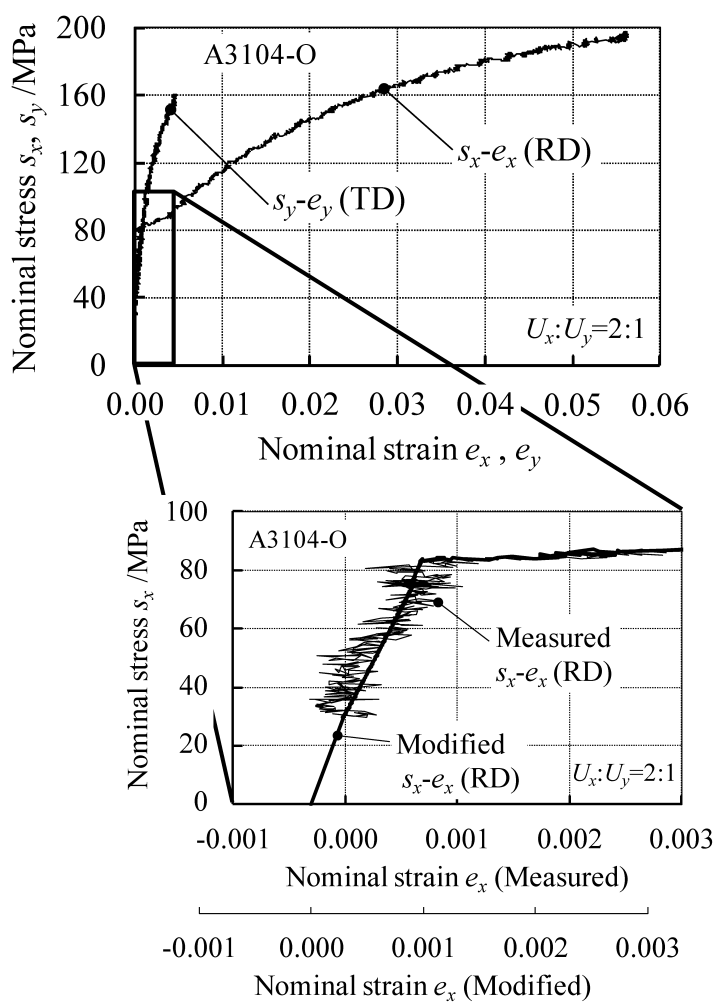

Fig. 7 Biaxial stress-strain curves obtained by the proposed apparatus.

\section{り修正する。}

·実験より得た最大主応力方向の公称応力-公称ひずみ曲線 より降伏点Yを定める。

・ひずみ 0 から降伏点 $\mathrm{Y}$ までの公称ひずみ $e_{x}, e_{y}$ については, 実験より得た公称応力 $s_{x}, s_{y}$ を用いて, 次式により求める。

$$
\begin{aligned}
& e_{x}=\left(s_{x}-v s_{y}\right) / E \\
& e_{y}=\left(s_{y}-v s_{x}\right) / E
\end{aligned}
$$

・降伏点から破断までに測定した全ひずみ $e_{x}, e_{y}$ については, 降伏点での公称ひずみの測定值から修正後の降伏点におけ る公称ひずみの差を加える。

上記の手順によって，予荷重の影響とひずみのばらつきを 修正した応力ーひずみ曲線を Fig. 7 の拡大図に示す。

\section{3. 本二軸引張試験方法の妥当性評価}

開発した変位比一定型二軸引張試験装置を島津製作所製

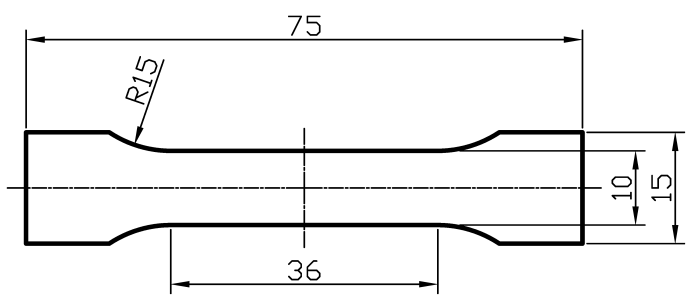

Fig. 8 Specimen for uniaxial tensile test.

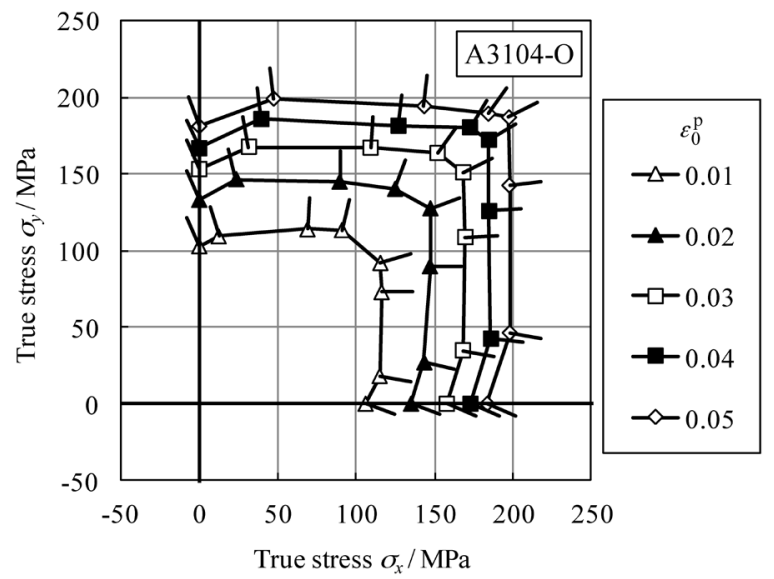

Fig. 9 Measured stress points forming contours of plastic work. Each symbol corresponds to a work contour for a particular value of $\varepsilon_{0}^{\mathrm{p}}$. The short lines attached to the stress points indicate the measured directions of the plastic strain rates at the associated stress points.

オートグラフ $(\mathrm{AG}-50 \mathrm{kNG})$ に取付けて二軸引張試験を行っ た。まず予備試験として, 本二軸引張試験方法の妥当性を評 価するために, 十字形試験片腕部の加工硬化により応力測定 部が塑性変形しやすい $\mathrm{A} 3104-\mathrm{O}$ 材（初期肉厚 $t_{0}=0.3 \mathrm{~mm}$ ）を 用いた。クロスヘッド速度は $1 \mathrm{~mm} / \mathrm{min}$, 試験片の圧延方向 を $x$ 軸と一致させ, 変位比は $U_{x}: U_{y}=1: 0,2: 1,1: 1,1: 2,0: 1$ で 実施した。また，Fig. 8 に示す形状の試験片を用いて圧延方 向および圧延直角方向の単軸引張試験も実施した。

アルミニウムの一般的なヤング率 $E=70 \mathrm{GPa}$, ポアソン比 $v=0.33^{10)}$ を用いて, 試験結果から 2.4 節に記載した方法に則 り，真応力・対数ひずみを定めた。

二軸引張応力下における加工硬化特性を定量的に評価する ため，等塑性仕事面を測定した。等塑性仕事面は，以下の手 順により求めた。まず圧延方向の単軸引張試験結果を用い て, 測定ひずみ範囲 $\varepsilon_{0}^{p}=0.01 \sim 0.05$ を 0.01 刻みとした既定の 対数塑性ひずみ $\varepsilon_{0}^{\mathrm{p}}$ を考え, この值に達するまでになされた塑 性仕事 $W^{\mathrm{p}}$ を求める。ついで, 二軸引張試験および圧延直角 方向の単軸引張試験結果から, $W^{\mathrm{p}}$ と等量の塑性仕事を与え る応力点 $\left(\sigma_{x}, \sigma_{y}\right)$ を求める。このようにして求めた等塑性仕 事面のプロット点を Fig. 9に示す。同図には各仕事点におけ る塑性ひずみ増分ベクトルの方向を併記する。等塑性仕事面 上の任意の応力点において, その応力点に関連する降伏曲面 は等塑性仕事面に接するというHillら ${ }^{11)}$ の推測を正しいも のとし, かつ降伏曲面に法線則が成り立つ, すなわち降伏曲 面を塑性ポテンシャルとみなせるならば, 塑性ひずみ増分べ クトルの方向は, 等塑性仕事面の外向き法線ベクトル方向と 一致する。本研究の二軸引張試験により測定された塑性ひず 


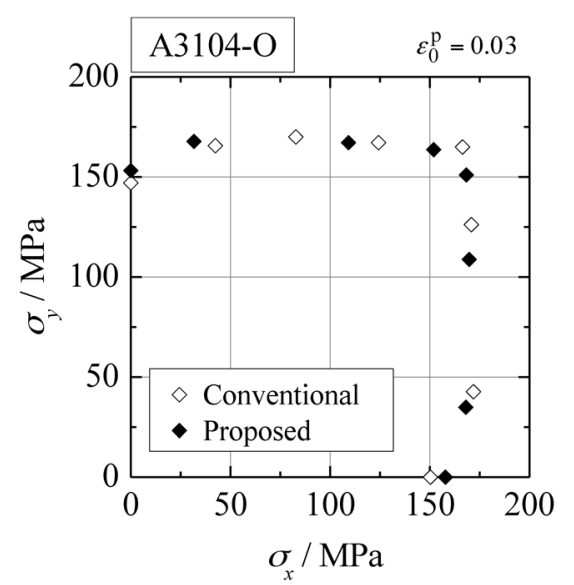

Fig. 10 Measured stress points forming the work contour for $\varepsilon_{0}^{p}=0.03$ compared with those measured using the conventional linear stress path experiments.

み増分ベクトルの方向は等塑性仕事面の法線ベクトルとおお むね一致しているとみなせる。つまり，今回の測定結果にお いては，等塑性仕事面を塑性ポテンシャルとみなすことが可 能である。

また, $\varepsilon_{0}^{\mathrm{p}}=0.03$ に招ける本試験結果と, 桑原らによって開発 された本研究よりも大きな試験片を対象とする応力比一定型 の二軸引張試験機 ${ }^{3)}$ によって得た結果を重ねて Fig. 10 に示 す。チャックの変位比が一定となる本試験装置によって得た デー夕は，実績のある応力比一定型の試験方法とほぼ同等の 結果を示しており，本試験方法が妥当であることを確認した。

\section{4. 負荷経路全図の提案}

桑原らによる十字形試験片を用いた二軸引張試験 ${ }^{3)}$ では, 応力測定部へ負荷する応力を応力比一定として制御する。一 方本試験装置では，十字形試験片を把持するチャックの変位 比は一定值に制御されるものの, 応力測定部の応力比やひず み比を直接制御できない。したがってこれらの比を一定に保 つことはできない。このため, 本試験方法から得た結果を, 応力-ひずみ曲線, 応力空間での経路図 $\left(\sigma_{x}-\sigma_{y}\right)$, あるいは ひずみ空間での経路図 $\left(\varepsilon_{x}-\varepsilon_{y}\right)$ として別々に表示しても，そ れぞれの対応を読取ることは難しい。

本試験結果を適切に明示するために，これらの負荷経路を 同時に表示する方法（以下，負荷経路全図）を提案する。一 例として, 変位比 $U_{x}: U_{y}=2: 1$ に拈ける負荷経路全図を Fig. 11 に示す。ここで示した曲線はvon Misesの降伏関数を仮定し た超小型十字形試験片の有限要素解析の結果を用いている。 この曲線では, 横軸右方向を正として $x$ 方向応力 $\sigma_{x}$ を, 縦軸 上方向を正として $y$ 方向応力 $\sigma_{y}$ を, 縦軸下方向を正として $x$ 方向ひずみ $\varepsilon_{x}$ を，横軸左方向を正として $y$ 方向ひずみ $\varepsilon_{y}$ をそ れぞれ示す。

この表記では主として, 応力経路 $\sigma_{x}-\sigma_{y}$ 曲線は第一象限に,

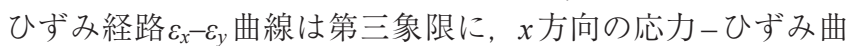

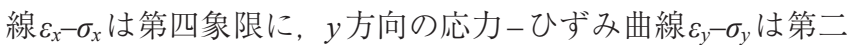
象限にそれぞれ表示される。

最大主応力方向（Fig. 11の場合 $x$ 方向）の $\varepsilon_{x}-\sigma_{x}$ 曲線より定 まる初期降伏点（第四象限の $\square$ 印）を起点として, 各軸に平 行な直線と Fig. 11 に示す他の3つの曲線との交点を順次結ぶ

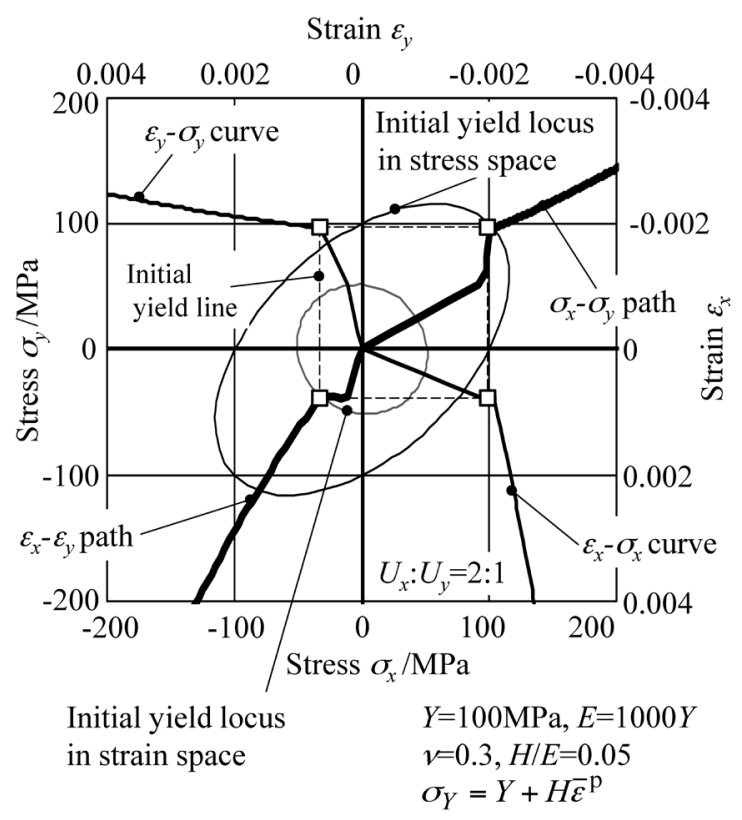

Fig. 11 Schematic illustration of the loading path diagram.

と, 図に示すように各曲線の初期降伏点を結んだ長方形を描 くことができる。本研究ではこれを破線で記し，初期降伏線 と呼ぶ。この表示方法によって, 各曲線における初期降伏点 を容易に特定することが可能となる。

\section{A3104-H材の二軸引張試験}

\subsection{A3104-H材の負荷経路全図}

3 章と同じ試験条件において, A3104-H材（アルミ缶ボ ディ用素板，板厚 $0.3 \mathrm{~mm}$ ）の試験を行い，2.4節に示した 弾性ひずみの修正により求めた負荷経路全図を Fig. 12 に示 す。なお，開発した二軸引張試験装置は多くのリンク節点 をもつため, $U_{x}: U_{y}=1: 1$ の設定においても水平方向チャッ クの変位が垂直方向チャックの変位よりもわずかに大きい。 このため, $U_{x}: U_{y}=1: 1$ の試験は圧延方向を装置の水平方向 とした場合と, 装置鉛直方向とした試験を行い, それぞれ $U_{x}: U_{y}=1: 1(1), U_{x}: U_{y}=1: 1(2)$ と表記する。

Fig. 12(a)には圧延方向, Fig. 12(h)には圧延直角方向の単 軸引張試験結果を示す。これらの試験では, 十字形試験片で はなく, 通常の単軸引張試験片を用いた。最大主応力方向の $\varepsilon-\sigma$ 曲線よりいずれの曲線もおよそ $300 \mathrm{MPa}$ で降伏している。

Fig. 12(c)に示した $U_{x}: U_{y}=2: 1$ の場合，第一象限に示される $\sigma_{x}-\sigma_{y}$ 曲線では $\sigma_{x}$ がおよそ $300 \mathrm{MPa}$ で折れ曲がり, その後降 伏点を迎える。一見すると $\sigma_{x}-\sigma_{y}$ 曲線の折れ曲がり点（以下， 変曲点）を降伏曲面に達した点と誤解しかねないが， $\varepsilon_{x}-\sigma_{x}$ 曲線との対応を考えると, この変曲点は降伏点とはいえな い。この変曲点での最大主応力 $\sigma_{x}$ は, 圧延方向での単軸引張 試験で得た降伏点（300 MPa 近傍）とほぼ一致している。つ まり, $\sigma_{x}-\sigma_{y}$ 曲線や $\varepsilon_{x}-\varepsilon_{y}$ 曲線に最初に現れる変曲点（第一変 曲点）は最大主応力方向の腕部が単軸応力場で降伏したこと により現れる変曲点であり, 応力測定域における真の降伏点 を示しているわけではない。真の降伏点は最大主応力方向で ある $\varepsilon_{x}-\sigma_{x}$ 曲線上で特定し, この点を起点として他の曲線と の交点を結んだ長方形により, 各曲線上における降伏点を正 確に明示することができる。 


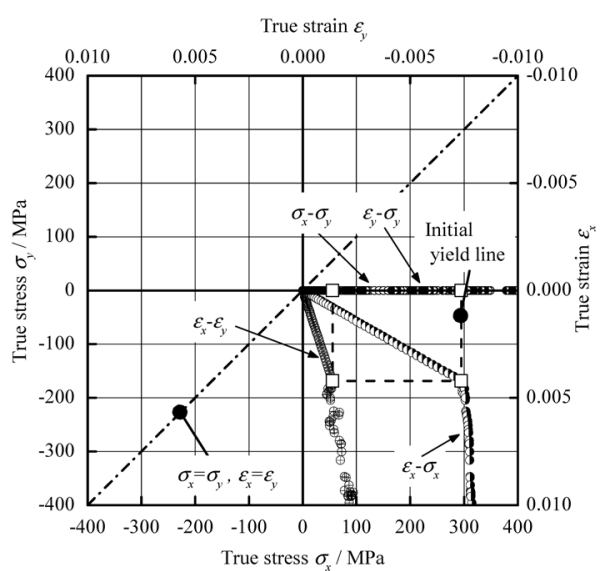

(a) $\sigma_{x}: \sigma_{y}=1: 0$

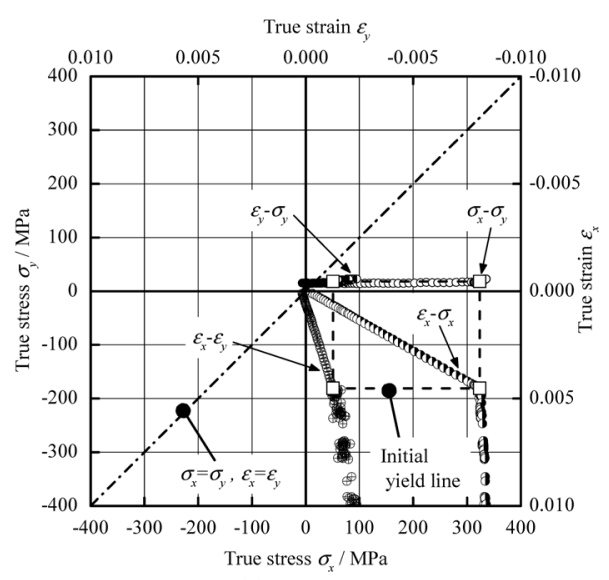

(b) $U_{x}: U_{y}=1: 0$
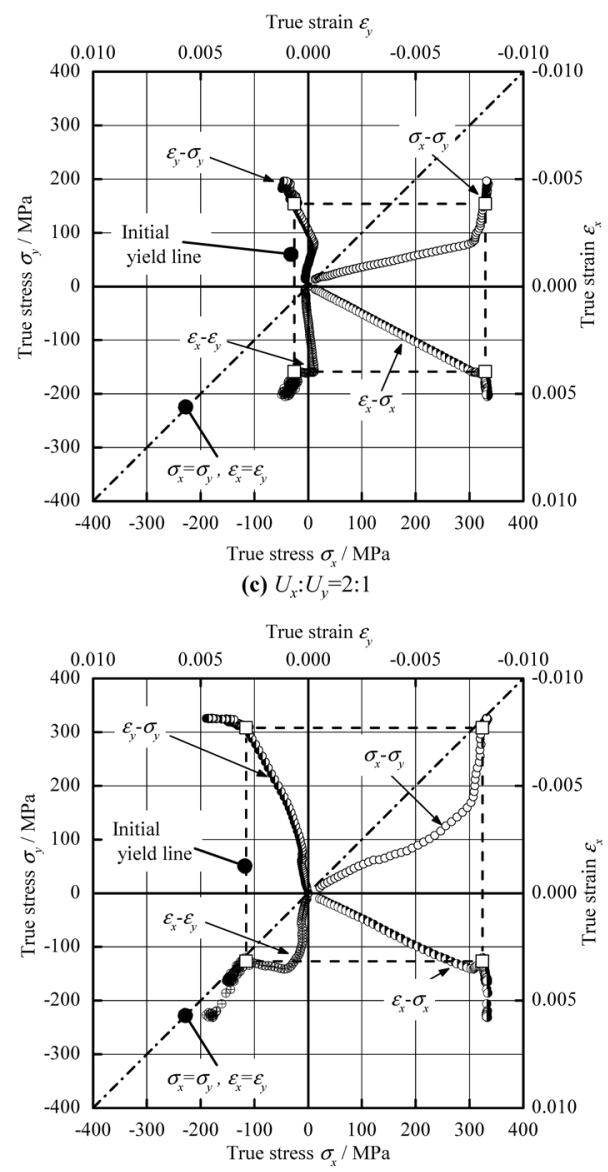

(d) $U_{x}: U_{y}=1: 1$ (1)
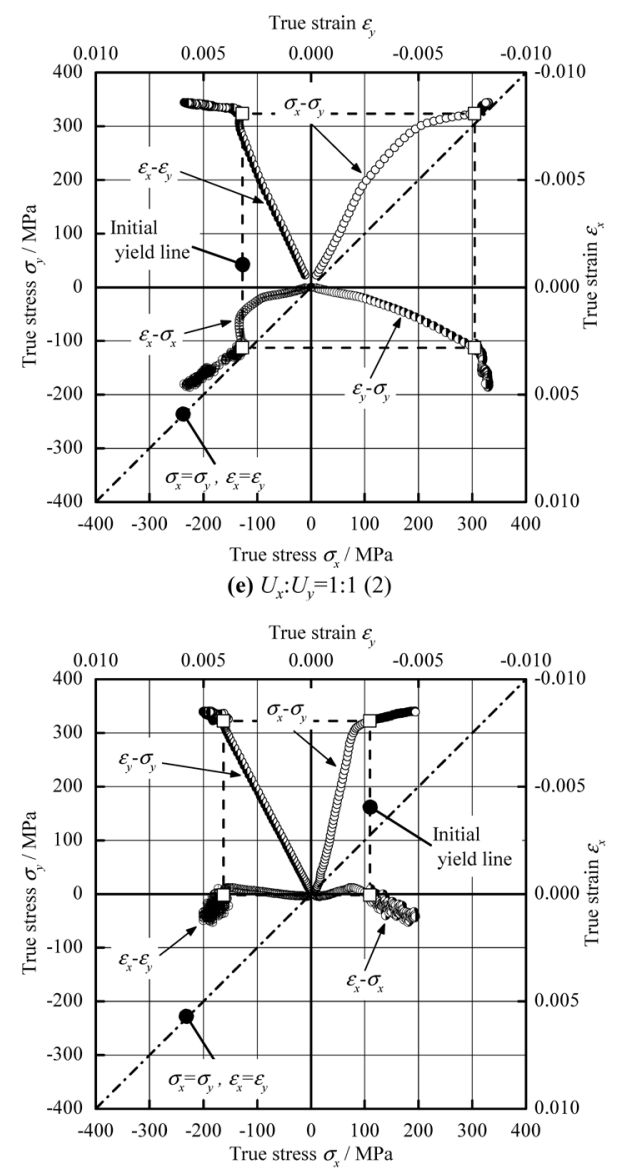

(f) $U_{x}: U_{y}=1: 2$

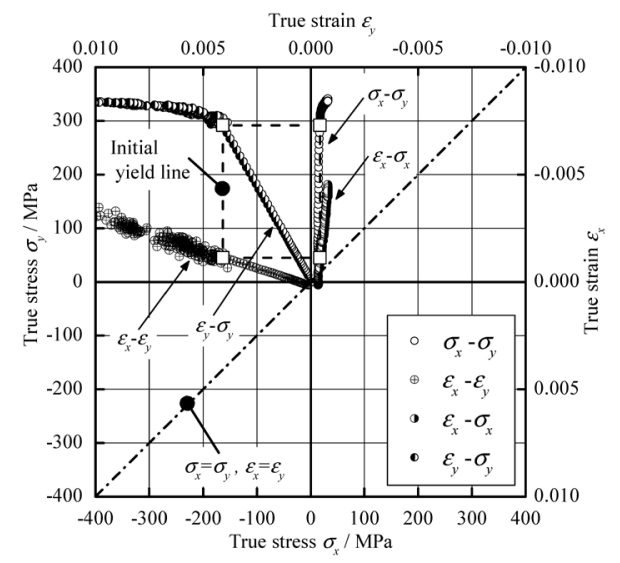

(g) $U_{x}: U_{y}=0: 1$

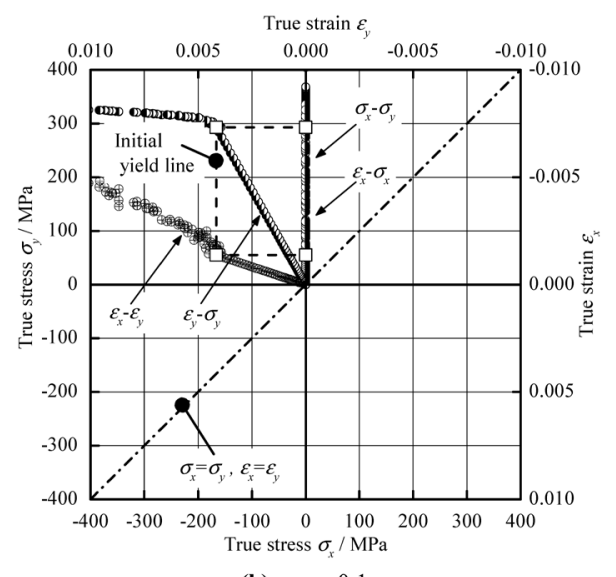

(h) $\sigma_{x}: \sigma_{y}=0: 1$

Fig. 12 Loading path diagrams for $U_{x}: U_{y}=1: 0,2: 1,1: 1,1: 2,0: 1$, and $\sigma_{x}: \sigma_{y}=1: 0,0: 1$ for A3104-H. 
Fig. 12(d)の第三象限に示される $\varepsilon_{x}-\varepsilon_{y}$ 曲線では $\varepsilon_{x}$ が 0.003 を 超えると大きく折れ曲がる。この折れ曲がりはFig. 12(c) と 同様に説明できる。この折れ曲がり箇所では，最大主応力方 向 $(x$ 方向）の腕部が単軸応力場で降伏して伸びるため, 同 方向の応力測定領域への变形の伝達は停滞する。一方, 最大 主応力に直交する方向 ( $y$ 方向) の腕部は弾性変形状態であ るため, チャック部変位 $U_{y}$ の増加により応力測定領域への 変形の伝達が継続する。このため, ひずみ経路に大きな折れ 曲がりが生じる。

変位比一定の二軸引張試験においては, 腕部の塑性変形に よって応力およびひずみの履歴は複雑な経路を描くが，提案 した負荷経路全図を用いることで試験法特有の応力およびひ ずみ状態の全体像を表現することができる。また，負荷経路 全図を用いることで，上述のように最大主応力方向の応力ー ひずみ曲線から応力空間における降伏点を特定することがで きる。

\section{2 等塑性仕事面}

$\mathrm{H}$ 材の二軸引張応力下における加工硬化特性を定量的に評 価するため，3章と同様の手順で等塑性仕事面を測定した。 等塑性仕事面を構成する応力点がすべての応力経路で測定で きたのは $\varepsilon_{0}^{\mathrm{p}}=0.0012$ までであった。一方，圧延方向の単軸引 張試験では $\varepsilon_{0}^{\mathrm{p}}=0.036$ まで，変位比 $1: 0$ では $\varepsilon_{0}^{\mathrm{p}}=0.005$ まで，変 位比 $2: 1$ では $\varepsilon_{0}^{\mathrm{p}}=0.0012$ まで, 変位比 $1: 1$ では $\varepsilon_{0}^{\mathrm{p}}=0.004$ まで, 変位比 $1: 2$ では $\varepsilon_{0}^{\mathrm{p}}=0.0012$ まで, 変位比 $0: 1$ では $\varepsilon_{0}^{\mathrm{p}}=0.006$ ま で，圧延直角方向の単軸引張試験では $\varepsilon_{0}^{\mathrm{p}}=0.036$ まで応力点が 測定可能であった。十字形試験片を用いた試験条件において 最大の対数塑性ひずみ $\varepsilon_{0}^{\mathrm{p}}$ であった 0.006 までのすべての測定 值をFig. 13 に示す。これは圧延方向の各等塑性仕事量に応 じた降伏応力 $\sigma_{0}$ で正規化されたグラフである。前述したよ うに, $\mathrm{H}$ 材は加工硬化指数 $(n$ 值) が小さいため, 応力測定 部を塑性変形させることが困難である。しかし，本研究で提 案した試験方法によって対数塑性ひずみ $\varepsilon_{0}^{\mathrm{p}}=0.0012$ まで等塑 性仕事面を測定することができた。同図には対数塑性ひずみ $\varepsilon_{0}^{\mathrm{p}}=0.0012$ の等塑性仕事面を用いて次式で示す Yld2000-2d 降 伏関数 $\phi^{12)}$ によってモデル化した降伏曲面を示す。ここで は相当応力, Mは降伏関数の次数である。

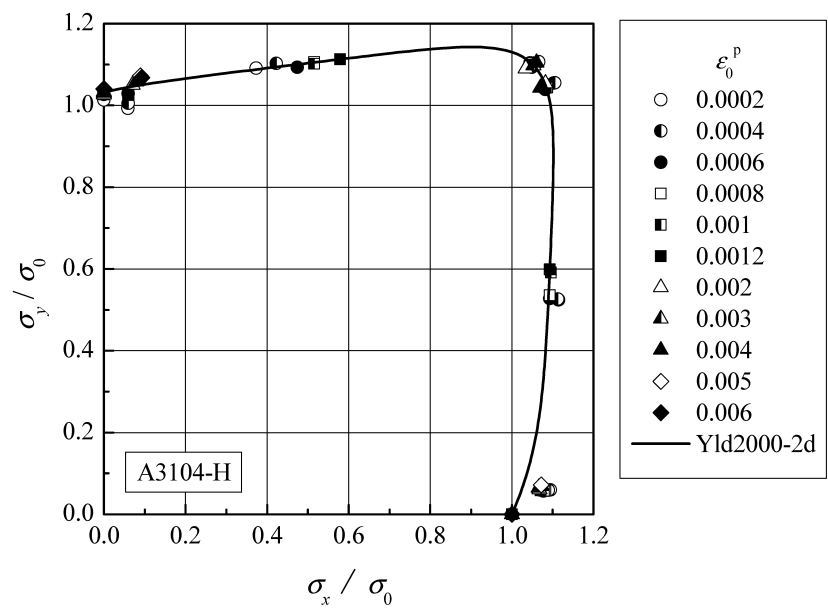

Fig. 13 Normalized measured stress points forming contours of plastic work, compared with the theoretical yield locus based on the Yld2000-2d yield function for $\varepsilon_{0}^{\mathrm{p}}=0.0012$.

$$
\phi=2 \bar{\sigma}^{\mathrm{M}}
$$

等塑性仕事面と降伏関数モデルとの誤差の自乗和が最小に なるように次数 $\mathrm{M}$ を決定した結果, 最適な次数 Mの值は 7.78 であった。

以上より，本研究で作製した十字形試験片および二軸引張 試験装置を用いれば，O材のみならず，加工硬化指数の小さ さゆえに初期降伏曲面の測定が困難とされる $\mathrm{H}$ 材に対しても 適用可能であることが示された。

\section{6. 結言}

加工硬化の小さい薄肉材の代表例として硬質アルミニウム 3104-H材を対象として，二軸引張応力場における局所的な 塑性変形特性の測定を目的として, 薄肉超小型試験片に適し た二軸引張試験方法を開発した。本研究で得られた知見は以 下の通りである。

（1）チャック変位比一定条件下での二軸引張試験の結果 から, 応力空間とひずみ空間における曲線を読み解くための 手法として，負荷経路全図を考案した。

（2）沉用の単軸引張試験機を駆動源とし, チャックの 変位比を変更可能なリンク機構を開発した。これを用いて A3104-O材の等塑性仕事面を測定した結果，本研究よりも大 きな試験片を対象とする応力比一定試験により測定されたそ れとほぼ一致した。これより，本二軸引張試験装置の妥当性 を示した。

（3） A3104-H材の二軸引張試験結果に対して負荷経路全 図の手法を適用し，最大で 0.0012 の相当塑性ひずみに対応す る等塑性仕事面の測定に成功した。さらに，測定された等塑 性仕事面は, 次数 M=7.78 の Yld2000-2d 降伏関数により近似 可能であることを明らかにした。

以上により，アルミ花ボディ用素板の二軸引張変形挙動を 測定し, その変形挙動を定量的に評価するための実験手法を 確立することができた。

\section{参 考 文 献}

1） 小出政俊，鶴田淳人：神戸製鋼技報， 55 (2005)，75-80.

2) 桑原利彦, 井上裕之, 花房泰浩, 伊藤隆一, 瀧澤英男 : 軽金属, 58 (2008), 449-455.

3) T. Kuwabara, S. Ikeda and T. Kuroda: J. Mater. Process. Technol., 80/81 (1998), 517-523.

4) 永安達哉, 高橋 進, 津藤哲也：第60回塑性加工連合講演会 講演論文集, (2009)，19-20。

5) 渡邊哲也, 黒田充紀: 第 61 回塑性加工連合講演会講演論文 集, (2010)，357-358.

6) Y. Hanabusa, H. Takizawa and T. Kuwabara: J. Mater. Process. Technol., 213 (2013), 961-970.

7)（財)機械システム振興協会：産業用次世代レーザー応用・開発 に関する調査研究報告書, (2009)，40.

8) Y. Hanabusa, H. Takizawa and T. Kuwabara: Steel Res. Int., 81 (2010), 1376-1379.

9) 花房泰浩, 瀧澤英男, 桑原利彦: 第 63 回塑性加工連合講演会 講演論文集，（2012），99-100 .

10) アルミニウムハンドブック第七版, 日本アルミニウム協 会, (2007), 32 .

11) R. Hill, S. S. Hecker and M. G. Stout: Int. J. Solids Struct., 31 (1994), 2999-3021

12) F. Barlat, J. C. Brem, J. W. Yoon, K. Chung, R. E. Dick, D. J. Lege, F. Pourboghrat, S. H. Choi and E. Chu: Int. J. Plast., 19 (2003), $1297-$ 1319. 